\title{
Review
}

\section{Early evolution of life cycles in embryophytes: A focus on the fossil evidence of gametophyte/sporophyte size and morphological complexity}

\author{
Philippe GERRIENNE* Paul GONEZ \\ (Paléobotanique, Paléopalynologie et Micropaléontologie Unit, Department of Geology, University of Liege, B-4000 Liege, Belgium)
}

\begin{abstract}
Embryophytes (land plants) are distinguished from their green algal ancestors by diplobiontic life cycles, that is, alternation of multicellular gametophytic and sporophytic generations. The bryophyte sporophyte is small and matrotrophic on the dominant gametophyte; extant vascular plants have an independent, dominant sporophyte and a reduced gametophyte. The elaboration of the diplobiontic life cycle in embryophytes has been thoroughly discussed within the context of the Antithetic and the Homologous Theories. The Antithetic Theory proposes a green algal ancestor with a gametophyte-dominant haplobiontic life cycle. The Homologous Theory suggests a green algal ancestor with alternation of isomorphic generations. The shifts that led from haplobiontic to diplobiontic life cycles and from gametophytic to sporophytic dominance are most probably related with terrestrial habitats. Cladistic studies strongly support the Antithetic Theory in repeatedly identifying charophycean green algae as the closest relatives of land plants. In recent years, exceptionally well-preserved axial gametophytes have been described from the Rhynie chert (Lower Devonian, $410 \mathrm{Ma}$ ), and the complete life cycle of several Rhynie chert plants has been reconstructed. All show an alternation of more or less isomorphic generations, which is currently accepted as the plesiomorphic condition among all early polysporangiophytes, including basal tracheophytes. Here we review the existing evidence for early embryophyte gametophytes. We also discuss some recently discovered plants preserved as compression fossils and interpreted as gametophytes. All the fossil evidence supports the Antithetic Theory and indicates that the gametophytic generation/sporophytic generation size and complexity ratios show a gradual decrease along the land plant phylogenetic tree.
\end{abstract}

Key words Devonian, early land plants, embryophyte, gametophyte, life cycle, sporophyte.

Plantae Haeckel 1866 (sensu Adl et al., 2005) are a monophyletic group of photosynthetic eukaryotes with: (i) a diplobiontic life cycle, that is, alternation of gametophytic and sporophytic generations; (ii) a cuticle; (iii) antheridia; (iv) archegonia; and (v) sporopollenin (Kenrick \& Crane, 1997a; Karol et al., 2001; Qiu et al., 2006; Gensel, 2008; Qiu, 2008). The latter character is shared with some Charophyceae (Delwiche et al., 1989). Plantae are also called embryophytes because the fertilization results in an embryo retained within the archegonium, or land plants because they live primarily in terrestrial habitats, in contrast with the related green algae that are primarily aquatic (Kenrick \& Crane, 1997a; Adl et al., 2005; Gensel, 2008; Qiu, 2008). Extant embryophytes include four lineages: the liverworts, the mosses, the hornworts, and the vascular plants (Fig. 1). The sporophyte of the extant liverworts

Received: 6 April 2010 Accepted: 27 August 2010

* Author for correspondence. E-mail: p.gerrienne@ulg.ac.be; Tel.: 32-43665363; Fax: 32-4-3665338. and mosses is small and matrotrophic on the dominant gametophyte. The hornwort sporophyte is persistently photosynthetic and erect. It is mostly matrotrophic on the haploid generation, but it can outlive the gametophyte and is therefore, to some degree, nutritionally independent (McManus \& Qiu, 2008, and references therein). Extant vascular plants have a dominant, nutritionally independent sporophyte and a reduced gametophyte. When and how the shift from gametophyte-dominant to sporophyte-dominant cycles occurred remains controversial, because the fossil evidence may be seen as ambiguous (Becker \& Marin, 2009). This paper proposes a critical review of the most significant data.

The evolution of sporophyte-dominant embryophytes during the whole Palaeozoic Era has deeply impacted terrestrial and marine ecosystems. Their colonization of the terrestrial environments resulted in the acceleration of the weathering processes and soil formation; it profoundly affected carbon cycling, changed the atmosphere composition, and irreversibly altered climates (Berner, 1997; Algeo et al., 2001; Berner, 


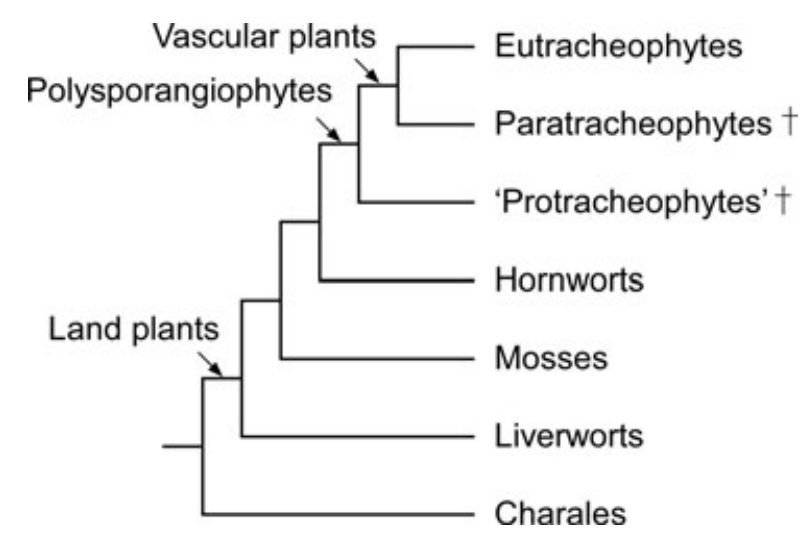

Fig. 1. Simplified phylogeny of Streptophytina Lewis \& McCourt 2004 (modified from Kenrick \& Crane, 1997b; Karol et al., 2001; Qiu et al., 2006; Gonez \& Gerrienne, 2010). "Protracheophytes" are a paraphyletic group of non-vascular polysporangiophytes (Kenrick \& Crane, 1991; Kenrick, 1994; Kenrick \& Crane, 1997a, 1997b). Paratracheophytes (formerly Rhyniaceae or Rhyniopsida) include early vascular plants with S-type water-conducting cells (Gerrienne et al., 2006). †Extinct taxa.

2001; Graham et al., 2004; Osborne et al., 2004; Beerling, 2005; Beerling \& Berner, 2005; Davies \& Gibling, 2010). An early step in the terrestrialization is probably illustrated by the Late Cambrian Agamachates casearius Taylor \& Strother 2009, that produces thickwalled spore-like palynomorphs enclosed within a packet characterized by a common wall. Agamachates casearius is interpreted as an intermediate condition between algae and embryophytes (Taylor \& Strother, 2009). The oldest uncontroversial records of embryophytes are mid-Ordovician $(\approx 472-461 \mathrm{Ma})$ with very simple spores, devoid of haptotypic mark such as trilete or monolete mark, termed cryptospores and presumably produced by early liverworts (Strother et al., 1996; Wellman et al., 2003; Rubinstein et al., 2010). The embryophytic affinities of Late Silurian cryptospore specimens have recently been unambiguously established (Steemans et al., 2010). The Late Silurian/Early Devonian fossil record includes embryophyte extinct lineages that are considered intermediate between the bryophyte grade and vascular plants: (i) the Late Silurian/Early Devonian mesofossil record is comprised of a wide range of small axes with centrally aggregated, elongate cells that show an almost continuous variation from smooth, uniform thin walls (suggesting affinities with bryophytes) to bilayered walls, the inner with annular or spiral thickenings (suggesting affinities with vascular plants) (Edwards, 2003; Edwards et al., 2003); (ii) the protracheophyte Aglaophyton Edwards 1986 is at a polysporangiophyte grade of organization but is devoid of thickened water-conducting cells (Kenrick \& Crane, 1991, 1997a, b); (iii) the paratracheophyte Rhynia has peculiar water-conducting cells with a very thin, apparently un- lignified, decay-resistant, inner layer covering a spongy layer (Boyce et al., 2003; Edwards, 1980; Kenrick \& Crane, 1991, 1997a, b) (Fig. 1). Cooksonia is considered as the earliest "true" vascular plant (eutracheophyte; Kenrick \& Crane, 1997b). Its vascular status has been demonstrated from Early Devonian (Lochkovian, $\approx 415 \mathrm{Ma}$ ) specimens (Edwards et al., 1992), but the plant first evolved during the second half of the Silurian $(\approx 430-416 \mathrm{Ma}$; Edwards \& Feehan, 1980). From the Late Silurian (Pridoli, $\approx 418 \mathrm{Ma}$ ) onwards, increasingly complex sporophytes were elaborated and land plant populations evolved from patchy stands of Cooksonia-type plants (a few centimetres high, isotomously branched, with terminal sporangia) to worldwide distributed forests dominated by Archaeopteris large trees at the end of the Devonian (late Famennian, $\approx 360 \mathrm{Ma}$; Meyer-Berthaud \& Decombeix, 2009; Gerrienne et al., 2010; Meyer-Berthaud et al., 2010).

Several reasons have been proposed to explain why vascular plants became by far the dominant embryophyte lineage. The efficiency of xylem and phloem for water and nutrient transport was obviously decisive. It helped vascular plants to considerably reduce their dependence on moist habitats and to invade a wide range of terrestrial ecological niches. The ability to synthesize lignin was also essential in the evolutionary adaptation of plants, allowing them to adopt an erect-growth habit in air (Qiu, 2008). Lignin prevents the collapse of conductive cells and provides biomechanical support to stems and roots. A further reason for the success of the vascular plants was the advent of the sporophyte, a diploid organism, as the dominant generation (Qiu et al., 2006; Niklas \& Kutschera, 2009a). Each sporophyte produces a large number of genetically diverse spores and hence gametes, which enhances fertilization efficiency; furthermore, diploidy allows a better resistance to environmental changes. It also reduces the impact of deleterious mutations and permits a large number of alleles to persist in the gene pool (Qiu et al., 2006).

For more than 100 years, the evolution of alternations of gametophytic and sporophytic generations in land plants has been discussed within the context of the Antithetic Theory and the Homologous Theory (Kenrick, 1994; Kenrick \& Crane, 1997b; Bennici, 2008; Haig, 2008; McManus \& Qiu, 2008; Niklas \& Kutschera, 2009a). The Antithetic Theory proposes a green algal ancestor with a gametophyte-dominant haplobiontic life cycle, the meiosis occurring after a number of mitotic divisions of the zygote. The Homologous Theory suggests a green algal ancestor with alternation of isomorphic generations, which means that the gametophyte and the sporophyte were approximately of the same size and morphology. A gradual reduction 
of the gametophyte occurred later, and, in parallel, the complexity and size of the sporophyte increased. The fossil record has often been interpreted as supporting the Homologous Theory, in contrast with most recent phylogenetic studies that unambiguously favor the Antithetic Theory. Here we review the evidence for early land plant life histories, with a special focus on the gametophyte/sporophyte size and morphological complexity ratios. We also discuss some recently discovered plants preserved as compression fossils and interpreted as gametophytes. Finally, we suggest a scenario for the early evolution of embryophyte life cycles.

\section{Antithetic Theory versus Homologous Theory}

The existence in embryophytes of pluricellular gametophytes and sporophytes has been known for a long time (Hofmeister, 1862) and has tentatively been explained by the mutually exclusive Antithetic and Homologous Theories.

The Antithetic Theory (or Interpolation Theory) was first proposed by Celakovsky (1874) and Bower (1890, 1908, 1935). It suggests that land plants are derived from a green algal ancestor with a haploiddominant haplobiontic life cycle and zygotic meiosis, such as that existing in extant Charophytes. The shift to diplobiontic life cycles was caused by: (i) the retention and nourishment of the zygote in the archegonium; and (ii) mitotic divisions of the zygote. The mitotic divisions of the zygote result in the interpolation in the life cycle of a pluricellular diploid generation, the sporophyte, which subsequently undergoes delayed meioses. The liverwort sporophyte is limited to a sporangium, a few millimetres long, with a short stalk; the sporophytes of some vascular plants are amongst the most massive organisms on Earth, more than $100 \mathrm{~m}$ high. Most recent phylogenetic studies unambiguously favor the Antithetic Theory in identifying the haplobiontic, gametophyte-dominant Charales as the closest living relatives to the embryophytes (Karol et al., 2001; Lewis $\&$ McCourt, 2004; Qiu et al., 2006; Turmel et al., 2006; Qiu, 2008; Becker \& Marin, 2009) (Fig. 1).

The Homologous Theory (or Transformation Theory) was proposed by Pringsheim (1876), Scott (1895), and Zimmermann (1930). It suggests that land plants are derived from a green algal ancestor with alternation of isomorphic generations such as Ulva. According to the proponents of this theory, a reduction and the final dependence of the sporophyte occurred in the bryophytes, and a reduction and the final dependence of the gametophyte occurred in the vascular plants. In recent years, ex- ceptionally well-preserved gametophytes have been described from the Early Devonian Rhynie chert (410 Myr old) (Remy \& Remy, 1980a; Remy et al., 1993; Kerp et al., 2004; Taylor et al., 2005). Those gametophytes are free-living organisms and consist of erect axes with archegonia or antheridia, generally borne within distal gametangiophores. Some of those gametophytes are tracheophytes. This fossil evidence has been interpreted as indicating the existence of morphologically complex, axial gametophytes in early vascular plants (Kenrick, 1994, 2000) and as supporting the Homologous Theory (Graham, 1993; Remy et al., 1993).

\section{Earliest evidence of alternation of genera- tions in land plants}

The production of dispersed, degradation-resistant spores is interpreted as indicating the existence of some degree of alternation of generations (Graham \& Wilcox, 2000), but is not necessarily restricted to embryophytes: the Late Cambrian Agamachates casearius, interpreted as an intermediate between algae and embryophytes, produces thick-walled spore-like palynomorphs (Taylor $\&$ Strother, 2009). The earliest unequivocal evidence of plants on land are cryptospores of mid-Ordovician age (Dapingian stage, $\approx 470 \mathrm{Ma}$; Rubinstein et al., 2010). Fragments of sporangia of late Ordovician age (Caradoc, $\approx 450 \mathrm{Ma}$ ) indicate that those spores were produced by a sporophyte within a specialized organ (Wellman et al., 2003). Cryptospore producing fossils are believed to have an affinity with liverworts (Strother et al., 1996; Wellman et al., 2003). All are fragmentary and do not give any indication on the respective size and complexity of the gametophytes and sporophytes.

\section{Rhynie chert gametophytes: Size matters}

The Rhynie chert is an Early Devonian Lagerstätte located near the village of Rhynie, (Aberdeenshire, Scotland). The fossil-bearing beds were discovered by Dr William Mackie at the beginning of the 20th century (Trewin, 2004). The age of the locality is Pragian or earliest Emsian (Early Devonian; Wellman, 2006). The discovery of the chert with exceptionally well-preserved organisms was a major paleontological breakthrough. The exquisite detail of preservation of the fossils allowed the description of the whole ecosystem, including plants, animals, fungi, a green alga, lichens, and cyanobacteria. Four free-living gametophytes have been described from the Rhynie chert. The correspondence has been proposed with four sporophytes (Remy et al., 1993; Kerp et al., 2004; Taylor 
et al., 2005). Lyonophyton rhyniensis Remy \& Remy $1980 \mathrm{~b}$ is interpreted as the gametophyte of Aglaophyton major (Kidston \& Lang) Edwards 1986; Kidstonophyton discoides Remy \& Hass 1991a is interpreted as the gametophyte of Nothia aphylla Lyon ex El-Saadawy \& Lacey 1979; Langiophyton mackiei Remy \& Haas $1991 \mathrm{~b}$ is interpreted as the gametophyte of Horneophyton lignieri (Kidston \& Lang) Barghoorn \& Darrah 1938; Remyophyton delicatum Kerp et al. 2004 is interpreted as the gametophyte of Rhynia gwynne-vaughanii Kidston \& Lang 1917. All of those gametophytes consist of unisexual, upright gametangiophores. Lyonophyton, Langiophyton, and Remyophyton are comprised of archegoniophores (female gametangiophores) and antheridiophores (male gametangiophores); Kidstonophyton only consists of antheridiophores (Kerp et al., 2004; Taylor et al., 2005). The complete life cycles of Aglaophyton, Horneophyton, and Rhynia have now been reconstructed (Kerp et al., 2004; Taylor et al., 2005; Niklas \& Kutschera, 2009a). They are generally described as demonstrating an alternation of more or less isomorphic generations (see the recent review provided by Boyce, 2010).

The discovery of all those exceptionally wellpreserved free-living axial gametophytes at Rhynie had an enormous impact on modern palaeobotany. It gave renewed support to the Homologous Theory of the origin of alternation of generations in embryophytes, and it is today generally admitted that alternation of isomorphic generations is the plesiomorphic condition among all early polysporangiophytes, including basal tracheophytes (Remy et al., 1993; Kenrick \& Crane, 1997a, 1997b; Kenrick, 2000). The cladistic study of Kenrick \& Crane (1997a, 1997b) showed that the early land plants with isomorphic life cycles were related to polysporangiophytes rather than to any bryophyte group. According to these authors, this indicates that the elaboration of isomorphic life cycles occurred in polysporangiophytes only and should not be interpreted as contradictory with the Antithetic Theory (Kenrick \& Crane, 1997b). All of this remains controversial, and the isomorphy of the life history of the Rhynie chert plants is arguable, as is the inference of the existence of such isomorphic life cycles in all early polysporangiophytes. Rather, various authors have suggested that some early polysporangiophytes might already have had a heteromorphic, diploid dominant alternation of generations (Gerrienne et al., 2006; Niklas \& Kutschera, 2009b; Strother, 2010). In order to address this, the life history of two emblematic early land plants from Rhynie, Aglaophyton and Rhynia, is described and discussed below.

Aglaophyton major (Kidston \& Lang) Edwards 1986 (Fig. 2) consists of a $20 \mathrm{~cm}$ tall plant with iso- tomously branched axes devoid of any epidermal outgrowths. Axes arise from a rhizome anchored with rhizoids. The sporangia are ovoid, up to $12 \mathrm{~mm}$ long, and radially symmetrical in transverse section. They are borne singly at the top of the axes. The central vascular strand is comprised of an inner zone of thin-walled cells, and of an outer zone of thick-walled cells (Kenrick \& Crane, 1997b). Water-conducting cells are smoothwalled and unpitted; they have been compared with hydroids, the water-conducting cells found in mosses (Edwards, 1986). In Kenrick \& Crane's (1997b) cladistic analysis, Aglaophyton is resolved as a basal polysporangiophyte on the basis of the absence of pitted waterconducting cells. A more detailed description of the plant is given in Kidston \& Lang (1920), Edwards (1986), Remy \& Hass (1996), Kenrick \& Crane (1997b), Edwards (2004), and Taylor et al. (2005).

Lyonophyton rhyniensis is presented as the gametophyte of Aglaophyton (Remy \& Remy, 1980b; Remy et al., 1993; Remy \& Hass, 1996; Taylor et al., 2005). Lyonophyton specimens are unisexual; male and female individuals have been discovered. Lyonophyton consist of erect axes at least $2.0 \mathrm{~cm}$ long; it is approximately 10 times smaller than Aglaophyton. Mature antheridiophores terminate in $2.8-9.0 \mathrm{~mm}$ across cup-shaped gametangiophores in which 10-40 stalked antheridia are produced. Mature archegoniophores consist of twice branched axes; their tip is slightly expanded with a central depression. Archegonia are slightly sunken in the epidermis and are found either on the axis segment just below the tip or in the depression. The gametophyte/sporophyte correspondence was established on the basis of similarities in conducting cell structure, epidermal cell pattern, stomatal organization, and association of gametophytes and sporophytes at the locality (Remy et al., 1993; Kenrick \& Crane, 1997b). Four developmental stages of Lyonophyton (globular teardrop-shaped - protocorm - gametangiophores) have recently been documented (Taylor et al., 2005). The life history of Aglaophyton/Lyonophyton has been fully illustrated by Taylor et al. (2005) and is presented here with the sporophyte and the gametophytes drawn approximately at the same scale (Fig. 2).

Rhynia gwynne-vaughanii Kidston \& Lang 1917 (Fig. 3) is a small plant, $15-20 \mathrm{~cm}$ high, with isotomously branched axes bearing small hemispherical projections that develop into adventitious lateral branches (Edwards, 1980). Axes are borne on a rhizome with rhizoids. The sporangia are fusiform, up to $5 \mathrm{~mm}$ long, and borne singly and subterminally at the top of the main axes; they are typically attached by means of a pad of tissue. The central vascular strand is comprised of S-type water-conducting cells. In Kenrick \& Crane's 


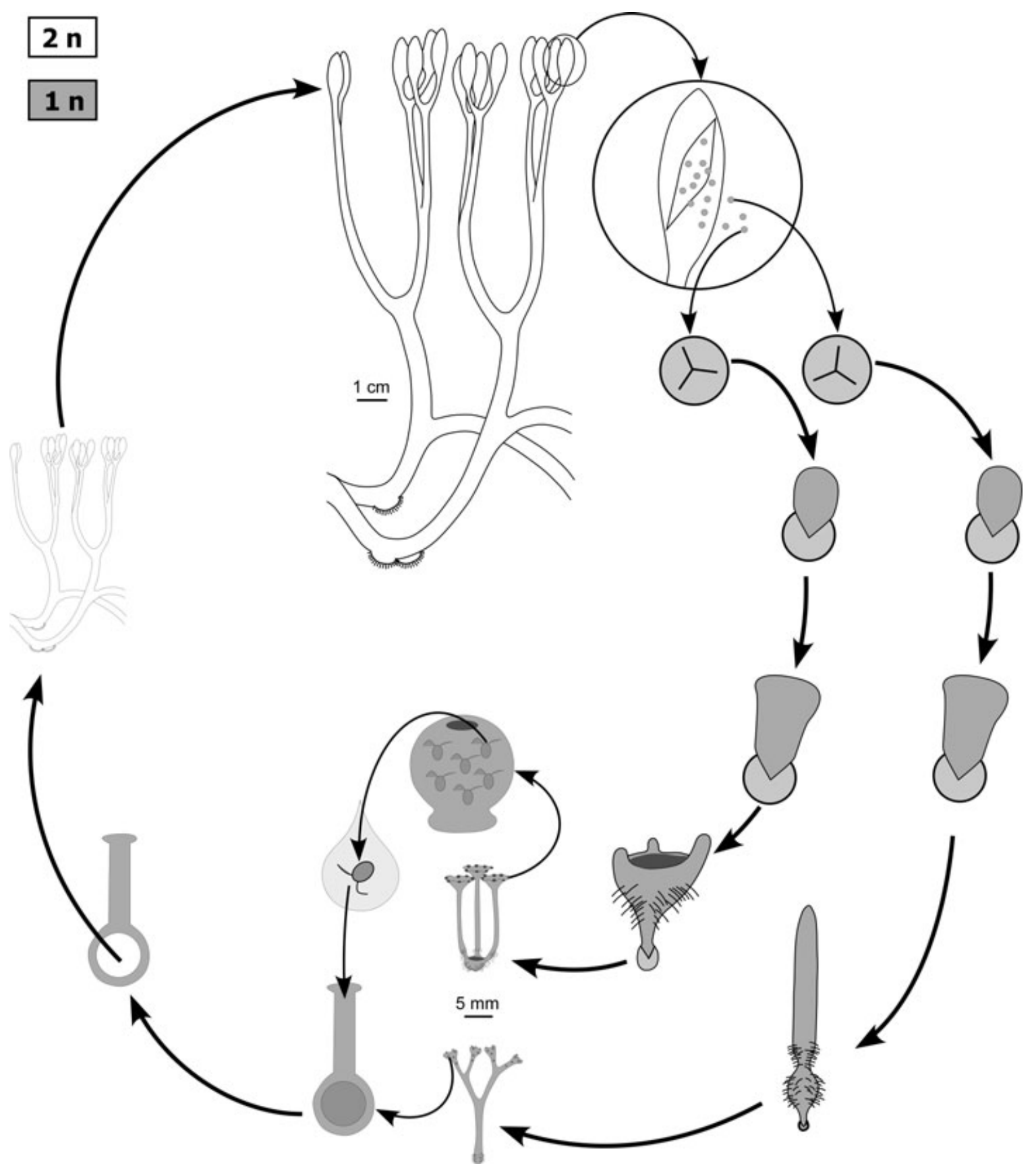

Fig. 2. Suggested reconstruction of the life history of Aglaophyton major (Kidston \& Lang) Edwards 1986 (modified from Taylor et al., 2005). The sporophyte and the gametophytes (Lyonophyton rhyniensis Remy \& Remy 1980b) are drawn approximately at the same scale. $1 \mathrm{n}=$ haploid generation (gametophyte); $2 \mathrm{n}=$ diploid generation (sporophyte).

(1997b) cladistic analysis, Rhynia gwynne-vaughanii was placed in the Rhyniopsida on the basis of several synapomorphies including the presence of S-type conducting cells. Rhyniopsida include several other genera and have been renamed Paratracheophyta (Gerrienne et al., 2006), a division that is sister to all other vascular plants (Fig. 1). A more detailed description of Rhynia gwynne-vaughanii is given in Kidston \& Lang
(1917), Edwards (1980), Kenrick \& Crane (1997b), and Edwards (2004).

Remyophyton delicatum is interpreted as the gametophyte of Rhynia gwynne-vaughanii. Remyophyton has been described from a single monospecific stand of completely preserved mature fertile axes (Kerp et al., 2004). The stand consists of rhizoid-bearing protocorms, up to $1.5 \mathrm{~mm}$ wide, each bearing one to four 


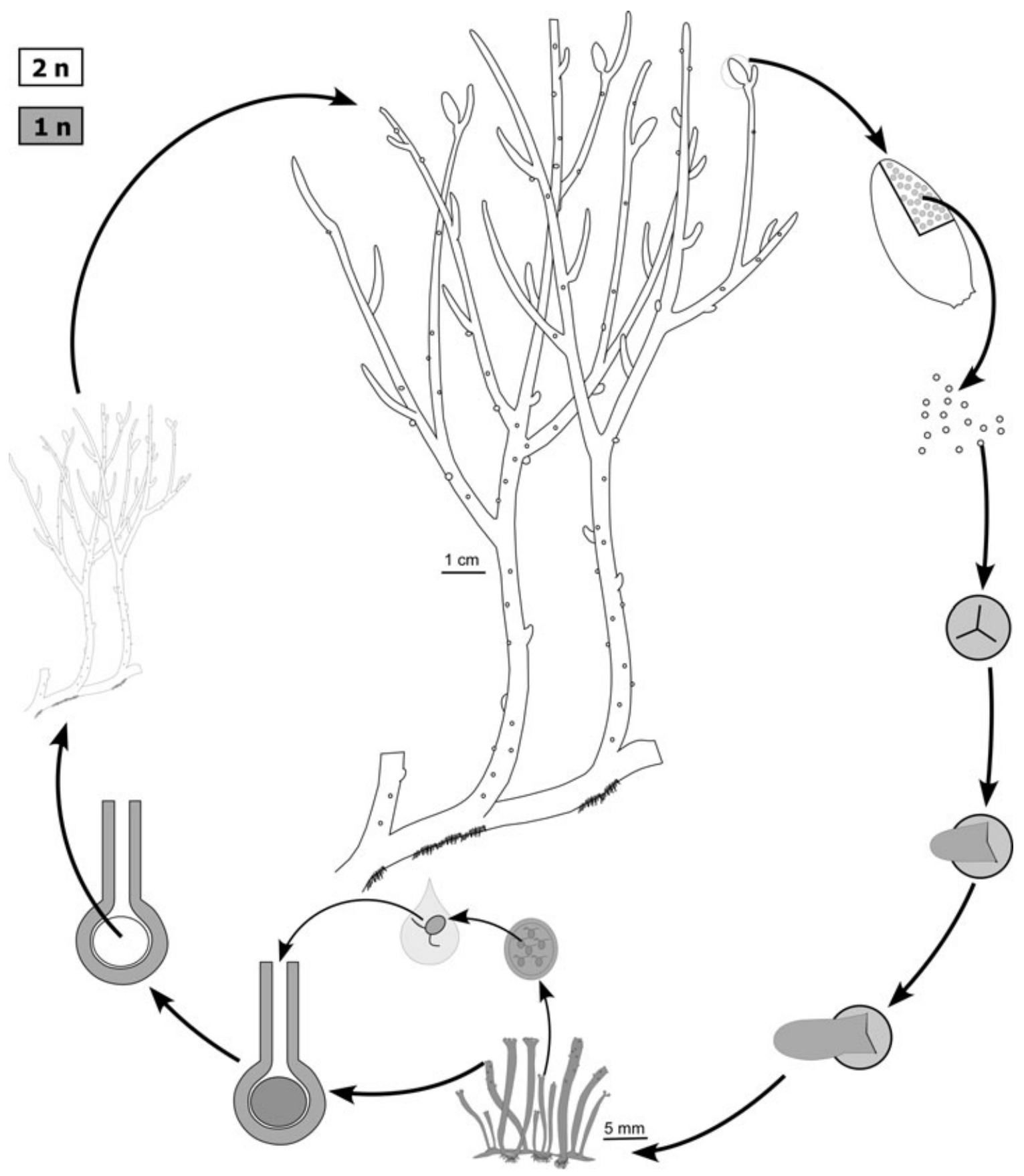

Fig. 3. Suggested reconstruction of the life history of Rhynia gwynne-vaughanii Kidston \& Lang 1917 (modified from Niklas \& Kutschera, 2009b). The sporophyte and the gametophytes (Remyophyton delicatum Kerp et al. 2004) are drawn approximately at the same scale. $1 \mathrm{n}=$ haploid generation (gametophyte); $2 \mathrm{n}=$ diploid generation (sporophyte).

unbranched erect axes bearing antheridia or archegonia. Protocorms exhibit variable morphologies ranging from globular to irregularly lobed or slightly bowlshaped. Remyophyton has erect axes $0.4-1.3 \mathrm{~mm}$ wide and $4-20 \mathrm{~mm}$ long; it is approximately 10 times smaller than Rhynia. The shorter fertile axes usually bear antheridia; the larger axes bear archegonia. Antheridia- bearing axes are terminally flattened or slightly bowlshaped, with antheridia placed at the top. Archegonia are lateral and subterminal on the larger axes. Axes have a central vascular strand with S-type conducting cells (Kerp et al., 2004). Aerial axes of Remyophyton possess the same anatomy and histology as young Rhynia axes (Kerp et al., 2004). The remarkably small size of 
Remyophyton as compared with Rhynia and with other plants of the Rhynie chert has been noticed by Kerp et al. (2004). The life history of Rhynia/Remyophyton has been described and discussed by Kerp et al. (2004), Taylor et al. (2005), and Niklas \& Kutschera (2009b), and reconstructed by Niklas \& Kutschera (2009a); it is presented here with the sporophyte and the gametophytes drawn approximately at the same scale (Fig. 3).

\section{Other Devonian gametophytes}

Most other Devonian plants interpreted as gametophytes consist of compression fossils. These are generally not preserved at a cellular level, hence their gametophytic status is sometimes arguable. Nevertheless, correspondences with some sporophytes have sometimes been suggested (see below). These putative correspondences associated with the large size and the erect habit of some of those gametophytes have led many workers to think that all early polysporangiophytes had isomorphic life cycles.

The Devonian record of liverworts includes the Middle Devonian Metzgeriothallus sharonae VanAller Hernick et al. 2008 and the Late Devonian Pallaviciniites devonicus (Hueber) Schuster 1966, both from New York State (USA). The two species are represented by thalloid gametophytes; a putative sporophyte (a fourvalved capsule attached to a broken stalk) is described for Metzgeriothallus (VanAller Hernick et al., 2008).

Sporogonites Halle 1916 has been collected from various Early Devonian localities worldwide (Kenrick $\&$ Crane, 1997b). The plant consists of undivided axes terminating in one large ovoid sporangium. The axes have been found attached to a thalloid structure (Andrews, 1960) that has been interpreted as a gametophyte (Andrews, 1960; Kenrick \& Crane, 1997b). One large specimen from the Early Devonian from Belgium (Stockmans, 1940, pl. IV: 6) shows several sporophytes apparently borne on one gametophyte; it is re-illustrated here (Fig. 4). On the basis of this possible association of a thalloid gametophyte and several unbranched sporophytes, Sporogonites has been interpreted as possibly representing a thalloid moss or an early hornwort (Poli et al., 2003).

Historically, the first plant described as a gametophyte has been Sciadophyton Steinmann (Kräusel \& Weyland, 1930). Sciadophyton Steinmann (sensu Remy et al., 1980) is the name applied to plants consisting of up to 30 axes, up to $10 \mathrm{~cm}$ long, radiating from a central region in a rosette fashion. The plant has been collected from the Early Devonian of Europe, Canada,

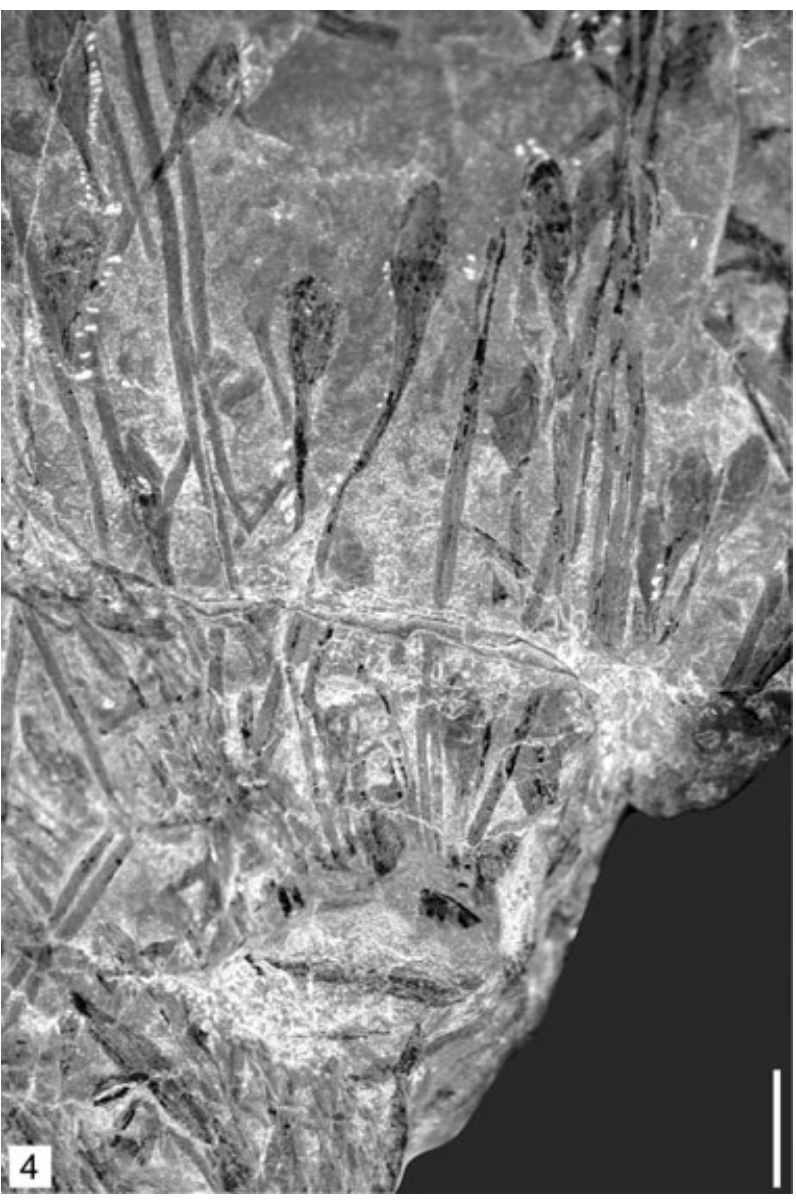

Fig. 4. Sporogonites Halle 1916 from Estinnes-au-Mont, an Early Devonian locality from Belgium. The specimen had already been illustrated by Stockmans (1940, pl. IV: 6). It consists of several undivided sporophytes apparently borne on one gametophyte. Scale bar $=5 \mathrm{~mm}$.

China (Remy \& Hass, 1991c), and Brazil (Gerrienne et al., 2001). The axes may be simple, isotomously branched, or bear secondary branches inserted at right angles (Remy et al., 1993). Axes have a central vascular strand with S-type conducting cells (Kenrick et al., 1991; Remy et al., 1993). Some axes end in a cup-shaped or plateau-shaped gametangiophore. The gametangiophores are often found flattened on the surface of the rock; they often exhibit lobed margins. Small organs interpreted as gametangia have been found attached on the surface of the gametangiophores (Remy et al., 1980; Remy et al., 1993).

On the basis of the frequent association of Stockmansella langii Stockmans, a member of the Paratracheophyta (Gerrienne et al., 2006) with Sciadophyton, Schweitzer (1983) suggested that the two plants might represent the sporophyte and gametophyte generations of the same plant. Sciadophyton also often occurs in close association with Huvenia spp., another 
paratracheophyte; this led Kenrick et al. (1991) to suggest that Sciadophyton might also be the gametophytic generation of Huvenia. The occurrence in the three genera of a central vascular strand with S-type conducting cells substantiates this suggestion. Together with Remyophyton, the axial gametophyte of the paratracheophyte Rhynia (Kerp et al., 2004), this body of evidence seems to indicate that the gametophyte generation of all members of the Paratracheophyta consisted of complex axial plants. These gametophytes were free-living, rather large but generally much smaller than the sporophytic generation.

Sciadophyton has also been tentatively described as the gametophyte generation of the early Lycophytina (sensu Kenrick \& Crane, 1997b) Zosterophyllum or Drepanophycus spinaeformis (Schweitzer, 1983, 1987; Remy \& Hass, 1991c). Apart from the occasional association of the plants in some fossiliferous beds (Schweitzer, 1983), this assumption is not supported by data. For example, both the central vascular strand of Zosterophyllum and Drepanophycus is comprised of G-type tracheids (Kenrick \& Crane, 1997b) and not of S-type water-conducting cells as in Sciadophyton.

Calyculiphyton blanai Remy et al. 1991 is known from the Early Devonian of Germany and Canada (Remy et al., 1991; Remy et al., 1993). The plant consists of usually undivided main axes, $1-2 \mathrm{~mm}$ wide and up to $20 \mathrm{~cm}$ long, with undivided, 2-6 $\mathrm{mm}$ long, lateral branches. Each lateral branch ends in one cup-shaped gametangiophore, $1.9-8.5 \mathrm{~mm}$ in diameter. Some gametangiophores are entire-margined, some others are lobed. Small organs located on lobed gametangiophores have been interpreted as gametangia (Remy et al., 1991, 1993). The architecture of the gametangiophores is reminiscent of that of the fertile structures of Sciadophyton. The anatomical structure of Calyculiphyton has not been documented, and its sporophyte has not been identified. Because of this lack of information, the implication of Calyculiphyton in the early evolution of embryophyte life cycles cannot be evaluated.

Schultka (2003) described an Early Devonian Cooksonia sp. from Germany on the basis of specimens consisting of rosettes of irregularly dichotomous axes borne on a central disk. The axes terminate in variously shaped and lobed structures that have been interpreted as sporangia (Schultka, 2003). The lobed outline of the terminal structures led Gerrienne et al. (2006) to suggest that these might represent gametangiophores, and that the whole plant could be interpreted as an axial gametophyte of the Sciadophyton-type.

Gerrienne et al. (2006) described one complete specimen of the early eutracheophyte Cooksonia paranensis Gerrienne et al. (2001) from an Early Devo- nian (early Lochkovian) locality from Brazil. The fossil is $33 \mathrm{~mm}$ high and consists of a cluster of five axial units. Each preserved distal axis segment of the specimen ends in one structure interpreted as a sporangium. All axes originate from a basal circular flattened organic structure, $3.0 \mathrm{~mm}$ in maximal diameter. The specimen (part and counterpart) is re-illustrated here (Figs. 5-7). Another specimen, slightly smaller, is visible on the same slab (Figs. 6,7). Three interpretations are possible for those specimens. (i) The whole specimens are gametophytes of the Sciadophyton-type, with a central area from which axes depart; under this interpretation, the terminal cups are gametangiophores. (ii) The basal structures represent a fragment of a rhizome bearing upright aerial axes, in which case the whole plants are sporophytes. (iii) The specimens are clusters of individual sporophytes still attached to the remains of presumably small and thalloid female or bisexual gametophytes. Gerrienne et al. (2006) were in favor of the third hypothesis. Other possible small thalloid gametophytes are scattered on the bedding plane of the rock (Figs. 8-11). In accordance with the third hypothesis, Gerrienne et al. (2006) proposed that their specimens of Cooksonia paranensis indicated that reduced thalloid gametophytes and branched axial sporophytes are plesiomorphic among the earliest eutracheophytes. A reconstruction of the life history of Cooksonia paranensis in accordance with the third hypothesis of Gerrienne et al. (2006) is proposed here, with sporophytes and gametophytes drawn at the same scale (Fig. 12).

One of us has recently discovered a putative fossil gametophyte from Pisa, another Brazilian Early Devonian (early Lochkovian) locality (P. Gonez, work in progress at Liege University). The specimen is preserved as an adpression. It consists of an undivided axis, $18 \mathrm{~mm}$ long and broken proximally (Fig. 13). The width of the axis increases regularly from $2 \mathrm{~mm}$ in the proximal part of the specimen to $6 \mathrm{~mm}$ distally. The apex is flat and exhibits an irregular outline. It bears several small rounded/elongated organs (Fig. 14). The morphology and the size of the specimen strongly recall the axial gametophytes from the Rhynie chert. Although no cellular detail is visible, we interpret it as presumably representing a fertile axial gametophyte with a terminal gametangiophore bearing gametangia. This putative gametophyte is much larger than the Cooksonia paranensis sporophytes, also present at the same locality (Fig. 15); both types of plants can be easily discriminated. The size and structure of this possible gametophyte are reminiscent of Lyonophyton or, to a lesser extent, to Remyophyton, and suggest that, during Early Devonian times, plants at a protracheophyte or 

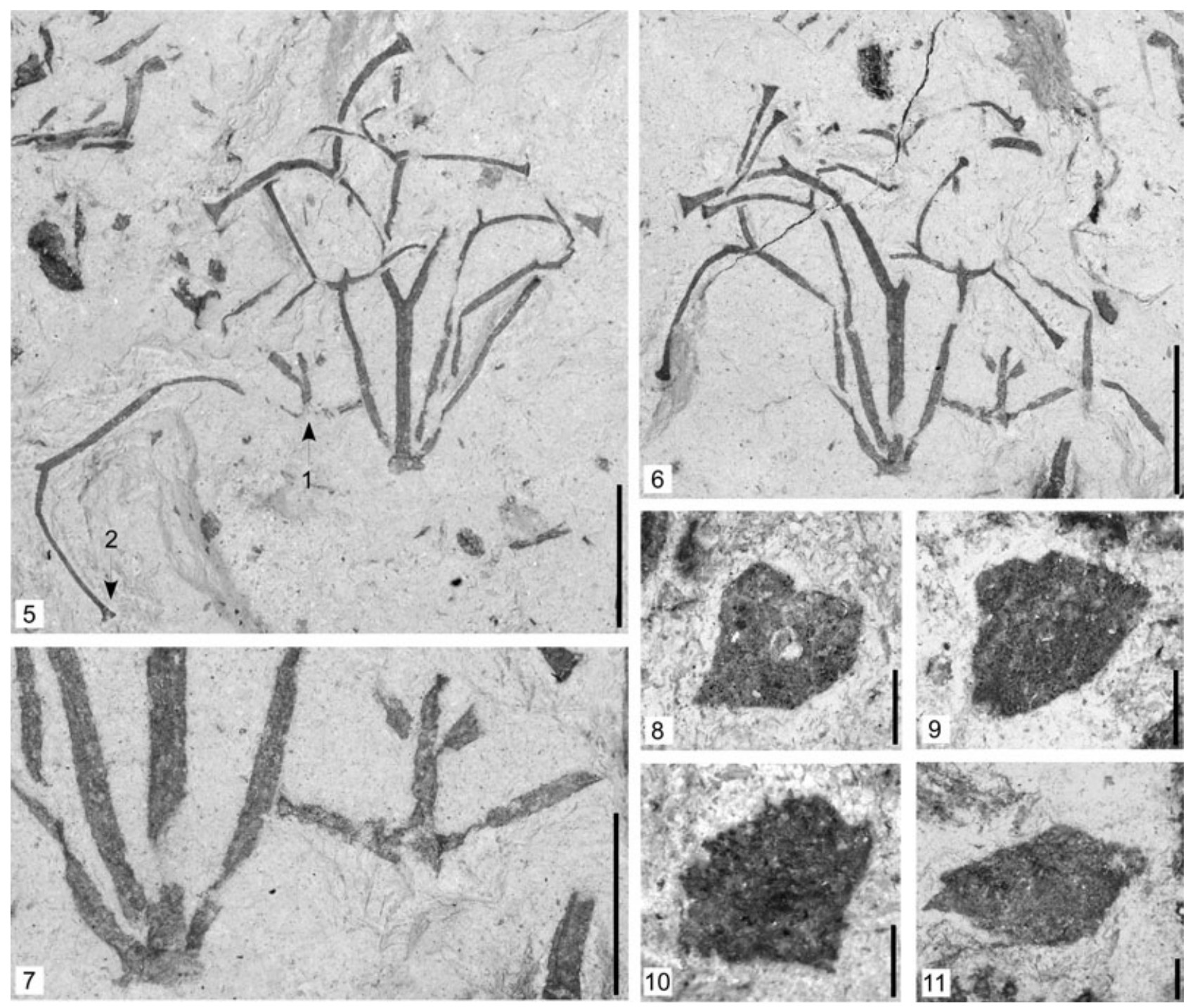

Figs. 5-11. Early land plants from Jackson de Figueiredo, an Early Devonian (early Lochkovian) locality from Brazil. 5. Specimen $13540 \mathrm{~A}$. A complete specimen of the early eutracheophyte Cooksonia paranensis Gerrienne et al. (2001). The fossil is $33 \mathrm{~mm}$ high and consists of a cluster of five axial units. Each preserved distal axis segment of the specimen ends in one structure interpreted as a sporangium. The basal circular flattened organic structure is interpreted as a small thalloid gametophyte. Another specimen, slightly smaller, is also visible (arrow 1); arrow 2 points to one sporangium of this specimen. Scale bar $=1 \mathrm{~cm}$. 6. Specimen $13540 B$. Counterparts of the specimens illustrated in Fig. 5 . Scale bar $=1 \mathrm{~cm}$. 7. Specimen $13540 B$. Enlargement of the base of two specimens illustrated in Fig. 6 . The specimen on the right is badly preserved, but a presumable small gametophyte and several sporophyte axes are visible. Scale bar $=5 \mathrm{~mm}$. 8-11. Specimen $13540 B$. Other possible small thalloid gametophytes. Scale bar $=1 \mathrm{~mm}$.

paratracheophyte grade of organization were present in South America.

The other occurrences of Devonian gametophytes are scarce. An endosporic megagametophyte has been described but not illustrated for the heterosporous progymnosperm Archaeopteris (Scheckler et al., 1997). The megagametophyte of the late Devonian early seed plant Elkinsia polymorpha is endosporic (Rothwell \& Serbet, 1992). All other Devonian early seed plants (Prestianni, 2005; Prestianni \& Gerrienne, 2010) are likely to have had a comparable type of female gametophyte. As noticed by Gerrienne et al. (2006), the Middle Devonian proto-ovule Runcaria Stockmans (Gerrienne et al., 2004; Gerrienne \& Meyer-Berthaud, 2007) presumably already possessed a heteromorphic alternation of generations with a reduced endosporic megagametophyte. All of this information is consistent with a rapid (in approximately 20 million years) reduction of the gametophytic generation in basal eutracheophytes. 


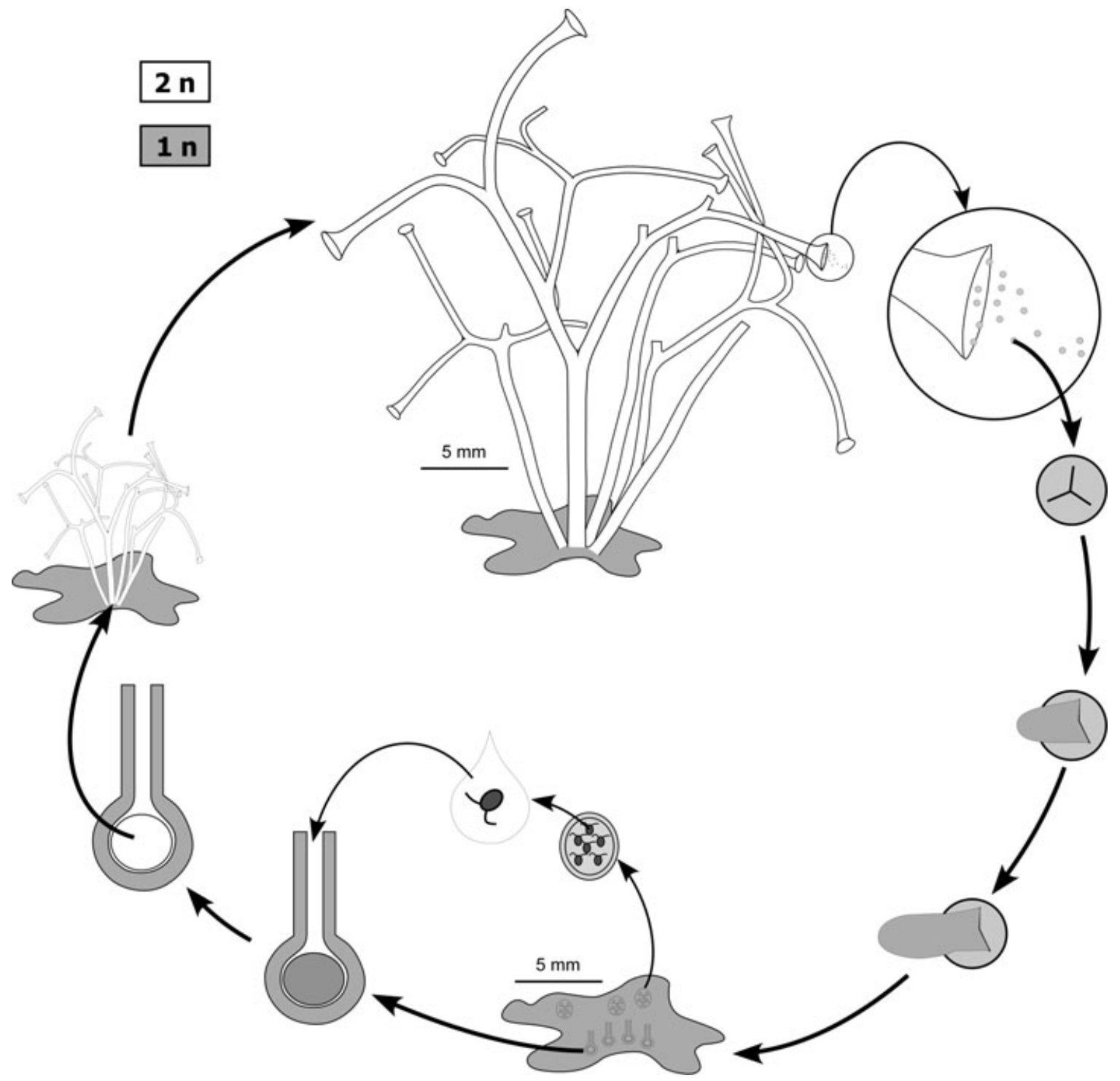

Fig. 12. Suggested reconstruction of the life history of Cooksonia paranensis Gerrienne et al. 2001. Sporophytes and gametophyte are drawn at the same scale. $1 \mathrm{n}=$ haploid generation (gametophyte); $2 \mathrm{n}=$ diploid generation (sporophyte).

\section{Discussion}

The evolutionary history of land plants (= Plantae or Embryophyta) has recently become increasingly clear. Land plants originated from charophycean green algae, with Charales being their most probable closest living relatives (Karol et al., 2001; Lewis \& McCourt, 2004; Qiu et al., 2006; Turmel et al., 2006; Qiu, 2008; Becker \& Marin, 2009). Most molecular studies identify: (i) liverworts as sister to all other embryophytes and as the earliest land plants (Qiu et al., 1998, 2006; Karol et al., 2001; Qiu, 2008); and (ii) hornworts as sister to vascular plants (Qiu et al., 2006, 2007). The shift from the haplobiontic, gametophyte-dominant life cycles of the Charales to the diplobiontic life cycles typical of land plants is best explained by the Antithetic Theory, which suggests that the diploid sporophyte generation was first added into the life cycle of land plant ancestors, and subsequently became increasingly large and complex. The minute size of the liverwort sporophytes is consistent with the Antithetic Theory.

The relationship between haploid and diploid generations in the four major lineages of extant embryophytes (liverworts, mosses, hornworts, vascular plants) is highly variable. The liverwort and moss sporophytes are matrotrophic and remain dependent on the 


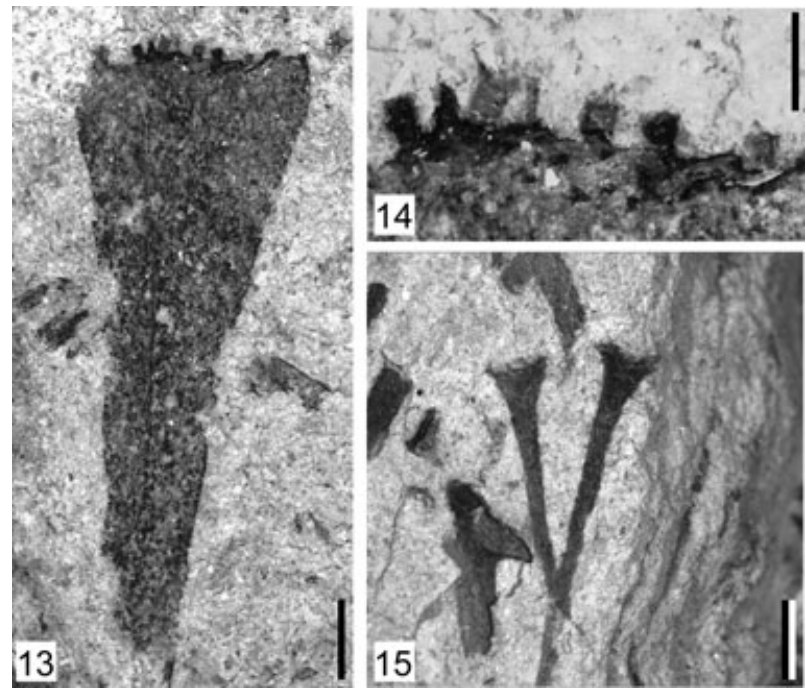

Figs. 13-15. Early land plants from Pisa, an Early Devonian locality from Brazil. 13. Specimen Pisa37. A putative fossil gametophyte. The specimen is preserved as an adpression; it is broken proximally. The apex bears several small rounded/elongated organs, enlarged in Fig. 14 Scale bar $=2 \mathrm{~mm}$. 14. Specimen Pisa37. Enlargement of the apex of a putative fossil gametophyte of Fig. 13. The small rounded/elongated bodies are interpreted as gametangia. Scale bar $=1 \mathrm{~mm}$. 15. Specimen Pisa144. An isotomously branched Cooksonia paranensis sporophyte. Two trumpet-shaped sporangia are visible. Scale $b a r=2 \mathrm{~mm}$.

gametophyte; in hornworts, the mature sporophyte is to some degree nutritionally independent (Qiu et al., 2006, 2007); in extant vascular plants, the sporophyte is very soon totally independent. The Early Devonian basal polysporangiophytes Aglaophyton and Rhynia had mature nutritionally independent gametophytes and sporophytes. The early growth of the sporophyte presumably occurred on the gametophyte, but so far this has not been demonstrated, as postfertilization stages have not been documented (Taylor et al., 2005). The sporophyte of Cooksonia probably grew on the gametophyte (Gerrienne et al., 2006), at least during the early growth stages. It has been suggested that the sporophytes of the smallest Cooksonia-like plants were unlikely to have been photosynthetically competent and that they were physiologically dependent on the gametophyte (Boyce, 2008, 2010).

If we consider the extant lineages of embryophytes only, there seems to be a rapid inversion of the gametophytic generation/sporophytic generation size and complexity ratio (Fig. 16): the gametophyte is much larger than the sporophyte within the liverworts, mosses, and hornworts, whereas the sporophyte is clearly the largest and the most complex generation within the vascular plants. On the basis of the discovery of independent, axial gametophytes from the Rhynie chert, it has been suggested that life cycles with large, complex game- tophytes characterized all basal polysporangiophytes, early eutracheophytes (lycophytes and euphyllophytes) included (Remy et al., 1993; Kenrick, 1994; Kenrick \& Crane, 1997a, b; Kenrick, 2000), and that gametophyte reduction occurred independently in lycophytes and euphyllophytes (Kenrick, 2000; Kenrick \& Crane, 1997a). Our critical analysis of all the fossil evidence, including recent discoveries (Kerp et al., 2004; Gerrienne et al., 2006), rather suggests that the gametophyte reduction had already occurred in embryophytes when basalmost eutracheophytes (i.e. plants at a Cooksonia-grade of organization) evolved (Fig. 16).

The axial, erect gametophytes discovered at the Early Devonian Rhynie chert show that the sporophyte of the basalmost polysporangiophyte to date (Aglaophyton) was already much larger that the gametophyte. However, the two generations were approximately of the same morphological and anatomical complexity, and the life cycle of the plant has been described as more or less isomorphic (Remy et al., 1993; Kenrick, 1994; Kenrick \& Crane, 1997a, b; Kenrick, 2000). The life cycle of the paratracheophyte Rhynia is of approximately the same type, with a small axial gametophyte and a much larger sporophyte (Kerp et al., 2004). The gametophyte generation was presumably even more reduced within the other vascular plant lineages (Fig. 16), as it has been suggested for the earliest eutracheophyte Cooksonia (Gerrienne et al., 2006). Accordingly, we suggest here the tiny size and presumably thalloid structure of the gametophytes of the earliest eutracheophytes account for the scarcity of the fossil record of free-living gametophytes.

Even when fossils are taken into account, there is still a major gap between the hornwort life cycle (small unbranched sporophyte borne on the gametophyte) and the life cycle of Aglaophyton (large, branched, independent sporophyte). Based on available evidence, it is impossible to tell whether the shift from one type of cycle to another occurred gradually or not. However, the gap between the two types of cycles is rather large, and it is likely that plants with intermediate grades of organization have existed. The earliest land plants evolved more than 50 million years before Aglaophyton. The biodiversity of the organisms that thrived during this period of time is largely undocumented, but a few examples suggest that plants with intermediate grades of organization might have existed. Edwards et al. (2003) have studied a large collection of minute coalified axes from an Early Devonian locality in the Welsh Borderland, Shropshire. Edwards et al. (2003) showed the existence within those simple fossils of a previously unsuspected wide range of anatomical diversity. Some specimens were described as showing a combination of characters 


\section{Diploid generation}

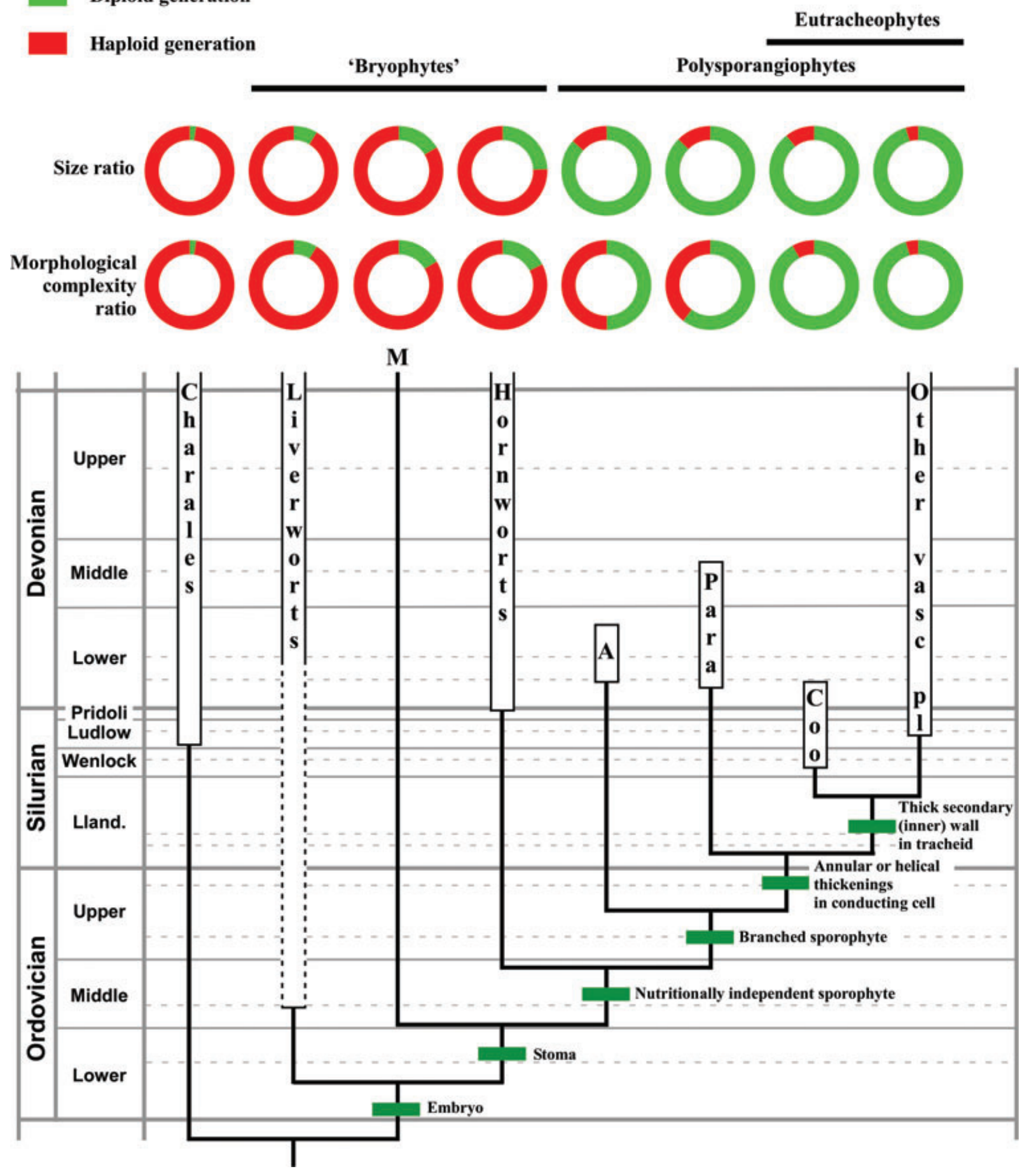

Fig. 16. Simplified phylogeny of Streptophytina Lewis \& McCourt 2004 (modified from Kenrick \& Crane, 1997b; Karol et al., 2001; Qiu et al., 2006; Gonez \& Gerrienne, 2010). The stratigraphic range of taxa demonstrated by fossils is indicated by vertical rectangles. Stratigraphic range of Charales from Feist et al. (2005). The gametophytic generation/sporophytic generation size (upper colored circles) and complexity (lower colored circles) ratios show a gradual decrease along the tree. Inverted commas indicate paraphyletic groups. A, the "protracheophyte" Aglaophyton, a plant at a polysporangiophyte grade of organization but devoid of thickened water-conducting cells (Kenrick \& Crane, 1991; Kenrick, 1994; Kenrick \& Crane, 1997a, 1997b); Coo, Cooksonia; Lland. = Llandovery; M, mosses; Para, Paratracheophytes (Gerrienne et al., 2006); vasc pl, vascular plants. 
not present in later bryophytes or tracheophytes (Edwards et al., 2003). Similarly, the Ordovician trilete spore assemblages of Steemans et al. (2009) might also represent a glimpse at a past biodiversity encompassing plants with grades of organisation intermediate between bryophytes and tracheophytes. Further research should aim at discovering and describing those transitional organisms, which should enable us to better understand and evaluate the evolution of life cycles in polysporangiophytes.

\section{Acknowledgements Philippe GERRIENNE is} deeply grateful to Yin-Long QIU for his invitation to give a lecture at the 2009 Botany and Mycology meeting (25-29 July, 2009; Snowbird, UT, USA). We thank Dr. M.-A. C. RODRIGUES, Dr. E. PEREIRA, and Dr. S. BERGAMASCHI from Rio de Janeiro State University for having given access to the Cooksonia material and for their help during fieldwork. We also thank Cyrille PRESTIANNI for his helpful comments. Philippe GERRIENNE is a Fonds de la Recherche Scientifique-FNRS Research Associate. Paul GONEZ holds a Fonds pour la Formation à la Recherche dans l'Industrie et dans l'Agriculture grant.

\section{References}

Adl MS, Simpson AGB, Farmer MA, Andersen RA, Anderson OR, Barta J, Bowser SS, Brugerolle G, Fensome RA, Fredericq S, James TY, Karpov S, Kugrens P, Krug J, Lane C, Lewis LA, Lodge J, Lynn DH, Mann DG, McCourt RM, Mendoza L, Moestrup Ø, Mozley-Standridge SE, Nerad TA, Shearer CA, Smirnov AV, Spiegel F, Taylor FJR. 2005. The new higher level classification of eukaryotes with emphasis on the taxonomy of protists. The Journal of Eukaryotic Microbiology 52: 399-451.

Algeo TJ, Scheckler SE, Maynard JB. 2001. Effects of Middle to Late Devonian spread of vascular land plants on weathering regimes, marine biotas, and global climate. In: Gensel PG, Edwards D eds. Plants invade the land: Evolutionary and environmental perspectives. New York: Columbia University Press. 213-236.

Andrews HN. 1960. Note on Belgian specimens of Sporogonites. The Palaeobotanist 7: 85-89.

Barghoorn ES, Darrah WC. 1938. Horneophyton, a necessary change of name for Hornea. Harvard University Botanical Museum Leaflets 6: 142-144.

Becker B, Marin B. 2009. Streptophyte algae and the origin of embryophytes. Annals of Botany 103: 999-1004.

Beerling DJ. 2005. Leaf evolution: Gases, genes and geochemistry. Annals of Botany 96: 345-352.

Beerling DJ, Berner R. 2005. Feedbacks and the coevolution of plants and atmospheric $\mathrm{CO}_{2}$. Proceedings of the National Academy of Sciences USA 102: 1302-1305.

Bennici A. 2008. Origin and early evolution of land plants:
Problems and considerations. Communicative \& Integrative Biology 1: 212-218.

Berner R. 1997. The rise of plants and their effect on weathering and atmospheric $\mathrm{CO}_{2}$. Science 276: 544-546.

Berner R. 2001. The effect of the rise of land plants on atmospheric $\mathrm{CO}_{2}$ during the Paleozoic. In: Gensel PG, Edwards D eds. Plants invade the land: Evolutionary and environmental approaches. New York: Columbia University Press. 173-178.

Bower FO. 1890. On antithetic as distinct from homologous alternation of generations in plants. Annals of Botany 4: 347370.

Bower FO. 1908. The origin of land flora: A theory based upon the facts of alternation. London: MacMillan \& Co.

Bower FO. 1935. Primitive land plants, also known as the archegoniatae. London: MacMillan \& Co.

Boyce CK, Cody GD, Fogel ML, Hazen RM, Alexander CMOD, Knoll AH. 2003. Chemical evidence for cell lignification and the evolution of tracheids in Early Devonian plants. International Journal of Plant Sciences 164: 691702.

Boyce KC. 2008. How green was Cooksonia? The importance of size in understanding the early evolution of physiology in the vascular plant lineage. Paleobiology 34: 179-194.

Boyce KC. 2010. The evolution of plant development in a paleontological context. Current Opinion in Plant Biology 13: 102-107.

Celakovsky L. 1874. Ueber die verschiedenen Formen und die Bedeutung des Generationwechsels der Pflanzen. Sitzungsberichte der koeniglichen Boehmischen Gesellschaft der Wissenschaften in Prague 2: 21-61.

Davies NS, Gibling MR. 2010. Cambrian to Devonian evolution of alluvial systems: The sedimentological impact of the earliest land plants. Earth-Science Reviews 98: 171-200.

Delwiche CF, Graham LE, Thomson N. 1989. Lignin-like compounds and sporopollenin in Coleochaete, an algal model for land plant ancestry. Science 245: 399-401.

Edwards D. 2003. Xylem in early tracheophytes. Plant, Cell and Environment 26: 57-72.

Edwards D. 2004. Embryophytic sporophytes in the Rhynie and Windyfield cherts. Transactions of the Royal Society of Edinburgh: Earth Sciences 94: 397-410.

Edwards D, Feehan J. 1980. Record of Cooksonia-type sporangia from late Wenlock strata in Ireland. Nature 287: 41-42.

Edwards D, Axe L, Duckett JG. 2003. Diversity in conducting cells in early land plants and comparisons with extant bryophytes. Botanical Journal of the Linnean Society 141: 297-347.

Edwards D, Davies KL, Axe L. 1992. A vascular conducting strand in the early land plant Cooksonia. Nature 357: 683685.

Edwards DS. 1980. Evidence for the sporophyte status of the Lower Devonian plant Rhynia gwynne-vaughnii Kidston and Lang. Review of Palaeobotany and Palynology 29: 177-188.

Edwards DS. 1986. Aglaophyton major, a non-vascular landplant from the Devonian Rhynie chert. Botanical Journal of the Linnean Society 93: 173-204.

El-Saadawy WE-S, Lacey WS. 1979. Observations on Nothia aphylla Lyon ex Høeg. Review of Palaeobotany and Palynology 27: 119-147. 
Feist M, Liu J, Tafforeau P. 2005. New insights into Paleozoic charophyte morphology and phylogeny. American Journal of Botany 92: 1152-1160.

Gensel PG. 2008. The earliest land plants. Annual Review of Ecology, Evolution, and Systematics 39: 459-477.

Gerrienne P, Meyer-Berthaud B. 2007. The proto-ovule Runcaria heinzelinii Stockmans 1968 emend. Gerrienne et al., 2004 (mid-Givetian, Belgium): Concept and epitypification. Review of Palaeobotany and Palynology 145: 321323.

Gerrienne P, Bergamaschi S, Pereira E, Rodrigues MAC, Steemans P. 2001. An Early Devonian flora, including Cooksonia, from the Paraná Basin (Brazil). Review of Palaeobotany and Palynology 116: 19-38.

Gerrienne P, Dilcher DL, Bergamaschi S, Milagres I, Pereira E, Rodrigues MAC. 2006. An exceptional specimen of the early land plant Cooksonia paranensis, and a hypothesis on the life cycle of earliest Eutracheophytes. Review of Palaeobotany and Palynology 142: 123-130.

Gerrienne P, Meyer-Berthaud B, Fairon-Demaret M, Streel M, Steemans P. 2004. Runcaria, a Middle Devonian seed plant precursor. Science 306: 856-858.

Gerrienne P, Meyer-Berthaud B, Lardeux H, Régnault S. 2010. First record of Rellimia Leclercq \& Bonamo (Aneurophytales) from Gondwana, with comments on the earliest lignophytes. In: Vecoli M, Clément G, Meyer-Berthaud B eds. The terrestrialization process: Modelling complex interactions at the biosphere-geosphere interface. London: The Geological Society of London Special Publications 339: 8192.

Gonez P, Gerrienne P. 2010. A new definition and a lectotypification of the genus Cooksonia Lang 1937. International Journal of Plant Sciences 171: 199-215.

Graham LE. 1993. Origin of land plants. New York: John Wiley \& Sons.

Graham LE, Kodner RB, Fisher MM, Graham JM, Wilcox LW, Hackney JM, Obst J, Bilkey PC, Hanson DT, Cook ME. 2004. Early land plant adaptations to terrestrial stress: A focus on phenolics. In: Hemsley AR, Poole I eds. The evolution of plant physiology. From whole plants to ecosystems. London: Elsevier Academic Press. 155-169.

Graham LE, Wilcox LW. 2000. The origin of alternation of generations in land plants: a focus on matrotrophy and hexose transport. Philosophical Transactions of the Royal Society of London B: Biological Sciences 355: 755-767.

Haeckel E. 1866. Generelle Morphologie der Organismen: Allgemeine Grundzuge der organischen Formen-Wissenschaft, mechanisch begrundet durch die von Charles Darwin reformirte Descendez-Theorie. Berlin: Georg Riemer.

Haig D. 2008. Homologous versus antithetic alternation of generations and the origin of sporophytes. The Botanical Review 74: 395-418.

Halle TG. 1916. A fossil sporogonium from the Lower Devonian of Röragen in Norway. Botaniska Notiser 1916: 79-81.

Hofmeister W. 1862. On the germination, development, and fructification of the higher Cryptogamia, and on the fructification of the Coniferæ. Piccadilly: Robert Hardwicke.

Karol KS, McCourt RM, Cimino MT, Delwiche CF. 2001. The closest living relatives of land plants. Science 294: 23512353.
Kenrick P. 1994. Alternation of generations in land plants: New phylogenetic and palaeobotanical evidence. Biological Reviews 69: 293-330.

Kenrick P. 2000. The relationships of vascular plants. Philosophical Transactions of the Royal Society of London B: Biological Sciences 355: 847-855.

Kenrick P, Crane PR. 1991. Water-conducting cells in early fossil land plants: Implications for the early evolution of tracheophytes. Botanical Gazette 152: 335-356.

Kenrick P, Crane PR. 1997a. The origin and early evolution of plants on land. Nature 389: 33-39.

Kenrick P, Crane PR. 1997b. The origin and early diversification of land plants. Washington: Smithsonian Institution Press.

Kenrick P, Remy W, Crane PR. 1991. The structure of water conducting cells in the enigmatic early land plants Stockmansella langii Fairon-Demaret, Huvenia kleui Hass et Remy and Sciadophyton sp. Remy et al. 1980. Argumenta Palaeobotonica 8: 179-191.

Kerp H, Trewin NH, Haas H. 2004. New gametophytes from the Early Devonian Rhynie chert. Transactions of the Royal Society of Edinburgh: Earth Sciences 94: 411-428.

Kidston R, Lang WH. 1917. On Old Red Sandstone plants showing structure from the Rhynie chert bed, Aberdeenshire. Part I. Rhynia gwynne-vaughanii, Kidston and Lang. Transactions of the Royal Society of Edinburgh 5: 761784.

Kidston R, Lang WH. 1920. On Old Red Sandstone plants showing structure, from the Rhynie chert bed, Aberdeenshire. Part II. Additional notes on Rhynia gwynne-vaughani Kidston and Lang; with descriptions of Rhynia major, n.sp., and Hornia lignieri, n.g., n.sp. Transactions of the Royal Society of Edinburgh 52: 603-627.

Kräusel R, Weyland H. 1930. Die Flora des Deutschen Unterdevons. Abhandlungen der Preussischen Geologischen Landesmuseum NF 131: 5-90.

Lewis LA, McCourt RM. 2004. Green algae and the origin of land plants. American Journal of Botany 91: 1535-1556.

McManus HA, Qiu Y-L. 2008. Life cycles in major lineages of photosynthetic eukaryotes, with a special reference to the origin of land plants. Fieldiana Botany 47: 17-33.

Meyer-Berthaud B, Decombeix A-L. 2009. L'évolution des premiers arbres: Les stratégies dévoniennes. Comptes-rendus Palevol 8: 155-165.

Meyer-Berthaud B, Soria A, Decombeix A-L. 2010. The land plant cover in the Devonian: A reassessment of the evolution of the tree habit. In: Vecoli M, Clément G, Meyer-Berthaud $\mathrm{B}$ eds. The terrestrialization process: Modelling complex interactions at the biosphere-geosphere interface. London: The Geological Society of London Special Publications 339: 59-70.

Niklas KJ, Kutschera U. 2009a. The evolutionary development of plant body plans. Functional Plant Biology 36: 682695.

Niklas KJ, Kutschera U. 2009b. The evolution of the land plant life cycle. New Phytologist 185: 27-41.

Osborne CP, Chaloner WG, Beerling DJ. 2004. Falling atmospheric $\mathrm{CO}_{2}$ - the key to megaphyll leaf origins. In: Hemsley AR, Poole I eds. The evolution of plant physiology. From whole plants to ecosystems. London: Elsevier Academic Press. 197-215. 
Poli D, Jacobs M, Cooke TJ. 2003. Auxin regulation of axial growth in bryophyte sporophytes: Its potential significance for the evolution of early land plants. American Journal of Botany 90: 1405-1415.

Prestianni C. 2005. Early diversification of seeds and seed-like structures. In: Steemans P, Javaux E eds. Pre-Cambrian to Palaeozoic Palaeopalynology and Palaeobotany. Carnets de Géologie / Notebooks on Geology, Brest, Memoir 2005/02, Abstract 06.

Prestianni C, Gerrienne P. 2010. Early seed plant radiation: An ecological hypothesis. In: Vecoli M, Clément G, MeyerBerthaud B eds. The terrestrialization process: Modelling complex interactions at the biosphere-geosphere interface. London: The Geological Society of London Special Publications 339: 71-80.

Pringsheim N. 1876. Über den Generationswechsel der Thallophyten und seinen Anschluss an den Generationswechsel der Moose. Monatsberichte der königlich Preussischen Akademie der Wissenschaften zu Berlin 1876: 869-911.

Qiu Y-L. 2008. Phylogeny and evolution of charophytic algae and land plants. Journal of Systematics and Evolution 46: 287-306.

Qiu Y-L, Cho YR, Cox JC, Palmer JD. 1998. The gain of three mitochondrial introns identifies liverworts as the earliest land plants. Nature 394: 671-674.

Qiu Y-L, Li LB, Wang B, Chen ZD, Dombrovska O, Lee J, Kent L, Li RQ, Jobson RW, Hendry TA, Taylor DW, Testa CM, Ambros M. 2007. A nonflowering land plant phylogeny inferred from nucleotide sequences of seven chloroplast, mitochondrial, and nuclear genes. International Journal of Plant Sciences 168: 691-708.

Qiu Y-L, Li L, Wang B, Chen ZD, Knoop V, Groth-Malonek M, Dombrovska O, Lee J, Kent L, Rest J, Estabrook GF, Hendry TA, Taylor DW, Testa CM, Ambros M, CrandallStotler B, Duff RJ, Stech M, Frey W, Quandt D, Davis CC. 2006. The deepest divergences in land plants inferred from phylogenomic evidence. Proceedings of the National Academy of Sciences USA 103: 15511-15516.

Remy W, Hass H. 1991a. Kidstonophyton discoides nov. gen. nov. spec., ein Gametophyt aus dem Chert von Rhynie (Unterdevon, Schottland). Argumenta Palaeobotanica 8: 29-45.

Remy W, Hass H. 1991b. Langiophyton mackiei nov. gen., nov. spec., ein Gametophyt mit Archegoniophoren aus dem Chert von Rhynie (Unterdevon Schottland). Argumenta Palaeobotanica 8: 69-117.

Remy W, Hass H. 1991c. Gametophyten und Sporophyten im Unterdevon-Fakten und Spekulationen. Argumenta Palaeobotanica 8: 193-223.

Remy W, Hass H. 1996. New information on gametophytes and sporophytes of Aglaophyton major and inferences about possible environmental adaptations. Review of Palaeobotany and Palynology 90: 175-193.

Remy W, Remy R. 1980a. Devonian gametophytes with anatomically preserved gametangia. Science 208: 295-296.

Remy W, Remy R. 1980b. Lyonophyton rhyniensis n. gen. et nov. spec., ein Gametophyt aus dem Chert von Rhynie (Unterdevon, Schottland). Argumenta Palaeobotanica 6: 37-72.

Remy W, Gensel PG, Hass H. 1993. The gametophyte generation of some Early Devonian plants. International Journal of Plant Sciences 154: 35-58.
Remy W, Remy R, Haas H, Schultka S, Franzmeyer F. 1980. Sciadophyton Steinmann - ein Gametophyt aus dem Siegen.). Argumenta Palaeobotanica 6: 73-94.

Remy W, Schultka S, Hass H. 1991. Calyculiphyton blanai, nov. gen., nov. spec., ein Gametophyt aus dem Ems. Argumenta Palaeobotanica 8: 119-140.

Rothwell GW, Serbet R. 1992. Pollination biology of Elkinsia polymorpha, implications for the origin of gymnosperms. Courier Forschungsinstitut Senckenberg 147: 225231.

Rubinstein CV, Gerrienne P, de la Puente GS, Astini RA, Steemans P. 2010. Early Middle Ordovician evidence for land plants in Argentina (eastern Gondwana). New Phytologist 188: 365-369.

Scheckler SE, Snigirevskaya NS, Hill SA. 1997. Endosporic gametophytes of the heterosporous Late Devonian (Famennian) progymnosperm Archaeopteris archetypus (= A.obtusa). American Journal of Botany 84: 141.

Schultka S. 2003. Cooksonia - Zur Morphologie einer frühen Landpflanze aus dem Unterdevon der Eifel. Courier Forschunginstitut. Senckenberg 241: 7-17.

Schuster RM. 1966. The Hepaticae and Anthocerotae of North Amercia, east of the hundredth meridian, vol. 1. New York: Columbia University Press.

Schweitzer H-J. 1983. Der Generationwechsel der Psilophyten. Berichte der Deutschen Botanischen Gesellschaft 96: 483 496.

Schweitzer H-J. 1987. Introduction to the plant bearing beds and the flora of the Lower Devonian of the Rhineland. Bönner Paläobotanische Mitteilugen 13: 1-94.

Scott DH. 1895. Nathanael Pringsheim. Nature 51: 399402.

Steemans P, le Hérissé A, Melvin J, Miller MA, Paris F, Verniers J, Wellman C. 2009. Origin and radiation of the earliest vascular land plants. Science 324: 353.

Steemans P, Lepot K, Marshall CP, Le Hérissé A, Javaux EJ. 2010. FTIR characterisation of the chemical composition of Silurian miospores (cryptospores and trilete spores) from Gotland, Sweden [online]. Review of Palaeobotany and Palynology. DOI: 10.1016/j.revpalbo.2010.07.006. Available from www.sciencedirect.com [accessed 25 September 2010].

Stockmans F. 1940. Végétaux éodévoniens de la Belgique. Mémoires du Musée Royal d'Histoire naturelle de Belgique 93: $1-90$.

Strother PK. 2010. Thalloid carbonaceous incrustations and the asynchronous evolution of embryophyte characters during the Early Paleozoic. International Journal of Coal Geology 83: 154-161.

Strother PK, Al-Hajri S, Traverse A. 1996. New evidence for land plants from the lower Middle Ordovician of Saudi Arabia. Geology 24: 55-58.

Taylor TN, Kerp H, Haas H. 2005. Life history biology of early land plants: Deciphering the gametophyte phase. Proceedings of the National Academy of Sciences USA 102: 58925897.

Taylor WA, Strother PK. 2009. Ultrastructure, morphology, and topology of Cambrian palynomorphs from the Lone Rock Formation, Wisconsin, USA. Review of Palaeobotany and Palynology 153: 296-309. 
Trewin NH. 2004. History of research on the geology and palaeontology of the Rhynie area, Aberdeenshire, Scotland. Transactions of the Royal Society of Edinburgh: Earth Sciences 94: 285-297.

Turmel M, Otis C, Lemieux C. 2006. The chloroplast genome sequence of Chara vulgaris sheds new light into the closest green algal relatives of land plants. Molecular Biology and Evolution 23: 1324-1338.

VanAller Hernick L, Landing E, Bartowski KE. 2008. Earth's oldest liverworts - Metzgeriothallus sharonae sp. nov. from the Middle Devonian (Givetian) of eastern New York, USA. Review of Palaeobotany and Palynology 148: 154-162.

Wellman CH. 2006. Spore assemblages from the Lower Devonian 'Lower Old Red Sandstone' deposits of the Rhynie outlier, Scotland. Transactions of the Royal Society of Edinburgh: Earth Sciences 97: 167-211.

Wellman CH, Osterloff PL, Mohiuddin U. 2003. Fragments of the earliest land plants. Nature 425: 282-285.

Zimmermann W. 1930. Die Phylogenie der Pflanzen; ein Überblick über Tatsachen und Probleme. Jena: G. Fischer. 